\title{
Post-transformational Trends in Hungarian Sport (1995-2004)
}

\author{
Gyöngyi Szabó Földesi
}

Semmelweis University, Faculty of Sport and Physical Education Sciences, Budapest, Hungary

ABSTRACT

KEYWORDS

The radical political and economic changes of 1989-1990 in Hungary affected all societal subsystems. In sport there was neither revolution from below nor relevant reforms from above prior to the regime change. The aim of this paper is to present the further development that are the posttransformational trends in Hungarian sport. The topic is approached from modernization perspectives. The information for the study was gained by various methods, such as analysis of documents, in-depth interviews, and participant observation. The results are analysed by three major dimensions: over-politicization, re-centralization, and paternalism. The findings show that the changes in sport were undergone in a very controversial manner, they were rather incremental than discontinuous. Neither a modernized sport model nor a national sport strategy on the basis of which a new model should have been built was founded. In Hungarian sport there seems to be an aversion and resistance to modernization. In conclusion the author states that Hungarian sport won a few battles, but it lost the war. A more democratic and a truly modern turnaround in the institution of sport is still expected. The transformation of Hungarian sport is continuing.

modernization, over-politicization, re-centralization, paternalism, participant observation

\section{Introduction}

The radical political and economic changes of 1989-1990 in Hungary affected all societal subsystems, but the time period, the speed and the pace of their transformation differ from each other considerably depending on their history, especially in the last decade of state socialism. With the exception of a few solitary protesters, in sport there was neither revolution from below, nor relevant reforms from above prior to the regime change. Endeavours for reforms emerged in sport later and in a narrower spectrum than in most other subsystems of society, and its transformation has made so little progress that it has been often questioned whether there has been a real system change in sport at all.

The transformation of sport in the countries of the former Eastern Bloc attracted surprisingly little interest among sociologists. The few exceptions were some outside observers (Riordan 1989, 1990, Heinemann 1990). The internal studies based on participant observation were hindered by the fact that the advent of political democracy caught sport scientists unprepared in most countries of the region, except for Poland and Hungary. In Poland, the only Eastern European country where sport sociology had a long tradition and was highly developed, comprehensive studies on the nature and 
directions of the recent changes in sport were published in the 1990s (Krawczyk 1992, 1997). In Hungary rather various partial topics have been analyzed in connection with the immediate impact of the 1989-1990 regime change on sport (Földesi 1993, 1996.) However research has not been carried out in related to the transformation of sport as a societal subsystem in the decade following the initial periods of the changes. The major purpose of this paper is to reveal the post-transformational trends in Hungarian sport, taking into consideration the legacy that affected this process.

\section{Theoretical Framework}

The topic discussed in the paper is approached from modernization perspectives. It is assumed that the major problems concerning the delay of the transformation of sport and the contradictory nature of its development are rooted in its lack of true autonomy. In Western democracies in the course of modernization the individual societal subsystems became autonomous gradually. This process of differentiation was followed by integration, but the political system did not dominate over economic and cultural systems. In the countries of the Eastern Bloc that followed the Soviet model the political system kept a firm hand on all subsystems. This domination might have originated from the fact that in the Eastern European societies the national economic capital was owned by the state and not by individuals. The political elite ("the party" nomenclature) controlled strictly not only politics but also the economy. One of the many negative consequences of this configuration was that it gave free scope for state paternalism. The individual societal subsystems lost their autonomy. They became totally dependent on politics; in fact they were at the mercy of ruling political power. Following the 19891990 political and economic transformation it was expected that this Eastern type of modernization would be changed and Hungary would follow the Western path of modernization. It was believed that in the process of political democracy most social institutions would regain their autonomy. In the last 15 years it turned out that most of them could not be autonomous, and could not do without state paternalism. The focus of this paper is on this group of problems in connection with sport.

\section{Methods}

Information for the analysis was gained by various methods, such as analysis of documents, in-depth interviews, and participant observations. Some basic documents containing the sport political concepts and objectives between 1990 and 2004 were selected for analysis ${ }^{1}$. In-depth interviews were made by key actors in sport in the same period $(\mathrm{N}=17)$. Participant observation was made by the author.

The transformational Hungarian society can be regarded as an immense social laboratory for studies into how changes on a macro-structural level affect the individual social institutions. The author of the thesis has been in the position to be a participant observer, because for the second part of the 1980s she has served national sport federations, and since the early 2000s she has been working as a volunteer in a national sporting confederation with the right and duty to make decisions as wel as in advisory committees with the highest decision-making bodies.

\footnotetext{
${ }^{1}$ In the research the following documents were analysed: LIII Act of 1920 on Physical Education; LXIV. Act of 1996 on Sport; II. Act of 1998 on the Amendment to the LXIV. Act of 1996 on Sport; XXXI. Act of 1998 on the Amendment to the LXIV. Act of 1996 on Sport; LXXXVI. Act of 1998 on the Establishment of the Ministry of Youth and Sport; CXLV. Act of 2000 on Sport; XCII Act of 2001 on the Amendment to the CXLV Act on Sport; Civil Strategy of the Government.of 2000; I. Act of 2004 on Sport. The major criteria of the analysis were the following: responsibility of the state, independence and structure of sport institutions, governmental control over sport, financing of sport, social functions attributed to sport.
} 


\section{Legacy}

Hungarian sport is widely believed to be a loser of the 1989-1990 political and economic transformations, with people both inside and outside of sporting circles arguing that it was devalued and that the state withdrew from it. In the mirror of our study this assumption seems to be true: sport as a societal subsystem appears indeed to be a loser of the regime change, but the interpretation and the explanation of the failure proved to be mistaken. No doubt, sport - in this context elite sport - was in an outstanding position during state socialism. It was provided with all financial means possible, even under the worst economic circumstances.

However the legacy on the grounds of which the transformation of sport inevitably had to start from, especially the relationship between sport and the existing, then disintegrating state socialist regime, is much more complex. Firstly, social inequalities could be witnessed even in elite sport. Since the late 1960s it became less open for young athletes from a working-class background, and inequality has increased continuously since that time. Secondly, other areas of sport, such as mass sport/ leisure sport, school sport, university sport, and sport for people with disabilities were in an unfavourable position in the decades of state socialism. The "weakest link" in the institutional legacy of today's Hungarian sport is indisputably related to the population's sporting activity. In principle the development of mass sport/leisure sport was regarded as equal with the promotion of elite sport. In reality it was always overshadowed and pushed into an underprivileged position. The privileged status of elite sport contributed to the fact that in the period of the disintegration of state socialism most actors in sport were reluctant to initiate changes and that the transformation of sport had a contradictory character.

\section{Initial Direction of the Changes}

In the initial part of the transformation the most important changes in sport were triggered from outside: they were the consequences of economic transformation and of the introduction of some general laws. The external political, economic, and social changes posed permanent challenges and the sports sphere seemed unable to give successful and adequate answers to them. It lacked a genuine, scientifically founded strategy for the reception of external changes and for the initiating of internal ones. Sport was missing the "creative minority" (interpreted in Toynbee's sense), which could induce successful answers. Although some intellectuals in sport have adopted a new way of thinking, their number and their organization lagged far behind the other subsystems of society. Top and middle management in sport were captives of the past in the sense that they expected the new state, the "omnipotent state", to find solutions to their new problems. Since it was not clarified unambiguously what role the state should play in sport, the problems were aggravated, the standards were conflicting and the roles were misinterpreted with increasing frequency (Földesi 1996, Takács 1996).

In the first six years following the system change there were a few changes in the supervisory authority and in the top management of sport, but the organizational structure and the middle management remained the same. The stress on continuity might have prevented sport from total collapse and deeper crisis in the short term, but the lack of more radical alterations in both managerial behaviour and structures certainly hindered sport from true transformation in the long term.

\section{Post-transformational trends}

Since the early 1990s consecutive governments in power have changed their approach to sport, however, several actions of their matching sport offices/ ministries seemed to have a surrogate nature 
with dysfunctional consequences. Instability can be illustrated by continuous structural and legal alterations. During 15 years four laws on sport were passed and the highest sport authority's organization was restructured six times. The political approach to sport by the individual government might have been different, but the very essence of their sport politics was rather similar. In their declared sport politics the core values were more or less the same: the unity of sport, the equality between the different fields of sport, the promotion of excellence, health and quality of life through sport. However, widespread disappointment was caused by the poor realization of these purposes in all periods.

All governments in power between 1990 and 2004 supported elite sport to a greater extent and all of them tried to gain political advantage from the Hungarian top athletes' performances directly or indirectly. In spite of huge differences in ideological reasoning, political culture and style, none of them could easily do without potential contribution of Hungarian sports successes to their legitimating. By so doing all of them missed the historical opportunity to radically change the political trend of traditional sport. Leisure sport, school sport, university sport could not really benefit from the system change, they were really losers. The only positive alteration occurred in sport for people with disabilities.

The unaltered priority of elite sport did not mean at all that elite sporting performers remained in the same privileged position. The differences between and within the individual branches of sport have been growing. The expectations of elite sport could not be met either, dissatisfaction has been increasing here as well, and was articulated by strong interest groups.

In the last 15 years neither the older nor the younger generations of sports managers accepted the altered position of elite sport in the new political democracy, nor were they able to cope with problems stemming from the new situation. Since the mid-1990s the climate has been more and more stressful in sport. The main actors accused each other mutually. The bulk of middle management argued that the interests of sport were not represented properly; more efforts were made by decisionmakers at organizational restructuring in sport according to their political concept than at finding new ways and drafting new strategies for its development. In return top managers blamed them for looking back instead of looking forward and for not contributing effectively to the shaping of a future sport model in a fresh spirit. The arguments on both sides could be supported by facts.

On the one hand, the continuous organizational restructuring did not appear to have generated relevant alterations. On the other hand, the approach to sport by middle managerial staff did not seem to have altered radically either. The two opposite sides have had one common denominator: in their understanding sport should be supported mostly, if not exclusively by the state. Distribution of public funds between the various fields of sport became the central issue. The fight for the public financial means has been sharpening and resulted in diminishing solidarity. The total lack of solidarity became a major feature of the sport world. The frequently replaced top management in sport was not capable of coordinating between the different interest groups; the social capital of the elite sport lobby could not been counterbalanced even by the most telling arguments.

The post-transformational trends in sport can be characterized by over-politicization, recentralization and paternalism.

\section{Over-politicization}

Although the direction of sport was dictated by political and economic imperatives, it remained free from strong political influence in the initial period of its transformation. It had been a 
field in which people with different ideological and political views were speaking the same language, the "language of sport". This ideal situation ceased to exist in the mid-1990s. For the second part of that decade sport has been the scene of political battles and rivalries.

When in the late 1990s the government in power moved to upgrade the Sports Office to ministerial rank, the idea was warmly welcomed and the world of sport celebrated that the affairs of sport were being raised to a ministerial level for the first time in its history. The idea to promote a generational change, to bring "fresh blood" into the management was not refused either at first glance. In theory, these two steps could have resulted in more independence, greater managerial freedom and more innovative action. In reality, it led to total disaster, because the new Ministry of Youth and Sport (MYS) not only decapitated the old managerial team but also "executed" it, which means that $80 \%$ (!) of the professional and technical staff employed by the former National Sports Office were fired. Hungarian sport has not yet recovered from this shocking measure, since the overwhelming majority of the new managerial staff have very limited experience both in sport and in management When selecting them it was not their professional knowledge but rather their loyalty to ruling power holders that counted for them in the first place.

The MYS made alterations in all possible spheres of sport: in its structure, functioning, legal background, even the regulation of granting awards and the naming of decorations were changed. In 1998 two amendments to the 1996 Act on Sport were adapted. In 2000 a new law on sport was issued. ${ }^{2}$ These legal acts seemed to be partly justified. However, the two amendments and the new law on sport aimed mostly to serve political purposes. In the changes there were both rational and irrational elements. For instance, it was a big step forward that for the first time in the history of Hungarian sport several areas of sport for people with disabilities received due attention and support. It also could have been advantageous that financial support originated from state income was guaranteed by law on sport for the promotion of the population's leisure sports activity. However the "Sport for All" movement could not really benefit of this potentially positive regulation, since the managerial staff in the Ministry systematically withheld or delayed the transfer of the legally guaranteed financial support, supposedly because of political considerations.

The budgetary support for sport was higher in that period than ever before or after in post-state socialism, but its distribution between the different spheres of sport was influenced by political reasons.

\section{CXLV. of 20000 on Sport}

The organizational restructuring of sport seemingly contributed to the democratization of the decision-making process. In fact it enhanced the state's role in it and helped to turn individual fields against each other. Similarly to wider society that started being divided in two "political camps" more and more acutely in those years, also in sport people voicing contrary opinions were not regarded any more as opponents but rather as enemies.

The government that came to power in 2002 also denied the institutional legacy in sport. The Ministry of Sport and Youth was restructured and given a new name, Ministry of Children, Youth and Sport (MCYS). The new Ministry introduced partly new structures, new objectives, and new financial policy. This time only the top management team was renewed, the middle management team remained basically the same. The realization of new objectives proved to be difficult with the old staff, many of which were loyal to political parties this time in opposition. The MCYS also passed a new law on sport $^{3}$ that was not built on a national sports strategy this time either, since its publishing was urged by political viewpoints. This law intended to induce some innovative changes; however it also contained 
irrational elements. For instance the guarantee of the financial support for the promotion of leisure sport was withdrawn and women's involvement in decision-making was not regulated any more. In this period not only the struggle between the major political forces, but contradictions within the bigger ruling party influenced the course of events. Within two years two ministers were assigned to the post, having diverse concepts on the direction of sport. Because of political considerations organizational restructuring occurred once more in the second part of 2004, and some changes were undertaken in early 2005. The ministerial rank of the highest sport authority was withdrawn; a National Sports Office was established, reporting firstly to the Prime Minister Office, then to the Ministry of Interior.

\section{I. Act of 2004 on Sport}

As a consequence, the Law of 2004 on Sport is not valid in several respects and an amendment to it is expected soon.

Several details were dissimilar but the fact that elite sport has also been given priority almost unalterably since 1990 cannot be denied. However the individual governments differed from each other substantially in their attitude and practice of exploiting active and former sportsmen for direct political purposes. The last illusion on the possibility for preserving the non-political nature of Hungarian sport was lost when in the early 2000s the biggest ruling party in power used the popularity of Hungarian Olympians by involving them in the electoral campaign and when in the same period the president of the (fundamentally non-political) Hungarian Olympic Committee, who was able to protect his relative independence over decades, including long periods in state socialism, committed himself to a political party in opposition that time. The HOC president's political commitment divided once again the world of sport in two and contributed strongly to the strengthening of over-politicizing tendencies.

\section{Re-centralization}

For analyzing sport as a social sub-system distinction is often made between three social orders, namely the state (public sector), civil society (voluntary sector), and the market (business sector). These sectors play different roles in regulating social life, dealing with special tasks, providing various social services and in solving different problems in society (Ibsen and Jorgensen, 2002). Overpoliticization could have gained ground in Hungarian sport since the late 1990s because neither the civil society nor the market could counterbalance the over-dominance of the state.

Civil society is based on the activity of autonomous individuals who lead a transparent, democratic public life and who are willing to work for it, gathering in groups and emphasizing the importance of free, local communities in the decision-making processes in the different areas of society. In this context civil society means various voluntarily organized groups whose members act together in diverse domains of social life in order "to express their interests, passions, and ideas, exchange information, achieve mutual goals, make demands on the state, and hold state officials accountable" (Diamond 1994).

Civil society is considered a vehicle for interaction between the state and its citizens. It can function effectively only under democratic conditions where the individuals are not at the mercy of governmental bodies and their interests are not subordinated to collective purposes, but where they are equals with them. Several contradictions in today's Hungarian sport are rooted in the lack of true civil 
sport organizations during state socialism, the particular nature of their rebirth in the early 1990s, and their odd status at present. In principle, civil organizations might be established if they have sufficient conditions in several respects. Most civil sports organizations in Hungary do not meet the criterion from an economic point of view. They expect not only to be supported financially, but also to be financed totally by public funds.

State intervention in sport is a critical issue concerning the relationship between the public and the voluntary sector. Due to the institutional legacy civil sport organizations has not become truly autonomous in the post-transformational years in Hungary. They can be identified as semiautonomous, sometimes with reasonable, sometimes with strong state intervention. The development of civil society has not been truly promoted by the state, its defencelessness was used to strengthen and to justify re-centralization tendencies.

At first sight a more recent restructuring in the early 2000s aimed at serving decentralization. By virtue of the Law on Sport issued in 2000, in 2001 three prominent public utility umbrella organizations representing the interest of different areas of sport were established: the National Sports Confederation, the National Leisure Sports Confederation, and the National Association of Disabled Athletes. They are non-profit associations and they function formally as voluntary organizations. In fact, they cannot be a vehicle for continuous interaction between the state and its citizens, since they are regulated by the state as their activities and finances are concerned. They enter into contact with the state, and by so doing their purely civil status is transformed into an intermediary one. Intermediary structures between governmental and non-governmental structures can be found in sport in several European countries. However, it depends on the power-holders whether they put the stress on their semi-voluntary or their semi-public nature. In post-transformational Hungarian sport intermediary sport structures have been often used to hide attempts at re-centralization. Therefore, in many respects they can be regarded as semi-public organizations, since although "de jure" they are partners, "de facto" they report to a governmental sports body. Even if they have a different concept they could mainly do only what is financed and approved by highest sports authorities. The decentralization of decision-making processes has not really happened. Both semi-civil and semipublic organizations have the right to express the opinion of citizens represented by them, but they have no real voice to influence the direction of sport.

\section{Paternalism}

For various reasons civil society has not been able to become an independent third sector in post-state socialist Hungary and to contribute to a strategy in connection with solving problems. The civil sector has been over-politicized and has lost its autonomy, civil movements have been institutionalized and have been overwhelmed by bureaucracy (Laskai 1999). In addition civil society failed to play a more decisive role in sport because it could not count on the business sector. The market principle has become legitimate in sport in post-state-socialist Hungary, but its growing legitimacy led mainly to a modest expansion of the commercial sector. In many European countries the financial contribution of the business sector to both professional sports and sports organized by the voluntary sector has increased considerably recently in the form of sponsorships.

In Hungary business sector has not been strong enough and has not been interested in supporting sport, especially not on a one-sided basis. The majority of top and middle managerial personnel have not learnt yet to act according to rules of the market, with most of them preferring to receive money to marketing. Most non-governmental sports organizations have been weak and fragile economically. Their economic situation can be characterized by lack of funds. Many of them have 
been in a desperate situation, close to liquidation, for 10-15 years. However, just a few of them have made true efforts to look after themselves. They have preferred patrons to sponsors, and they have regarded the state as patron number one. The best (or worst) example is the case of the Hungarian Olympic Committee. Because of the popularity of Olympism in Hungary the HOC has a huge advantage in marketing and obtaining support from sponsors. However its activity has been based on public money; for instance in 2002 about $80 \%$ of its income originated from public money, and only $15.6 \%$ from sponsors.

It is true that the budgetary support from the central state budget to sport in Hungary at present is significantly lower than in most countries in the European Union ( $0.2 \%$ versus $1,5-2.0 \%)$. Similarly, the whole civil sphere has been considerably under-financed by state budget-funded sources, both centrally and locally. For instance, in $200028.4 \%$ of the total income in the civil sector came from central or regional or local governmental budgets. This proportion reached $30 \%$ in 2002, but it is still far from the proportion required of countries of the European Union.

The National Civil Strategy (NCS) of the Government in office in 2002 discussed the postulates and the elements of the civil strategy of the government, drafting a comprehensive short program. ${ }^{4}$ But in this document there is just one reference to sport. The sport lobby does not seem to have contributed to the preparatory work of this strategy. The importance of the NCS was only recognized later in sport, when it was realized that the National Civil Foundation could be a new financial source. Many formally voluntary sports organizations have not had yet identified themselves as civil organizations. Organizational changes in sport have been rather incremental than discontinuous and continuity can be also observed regarding paternalistic expectations by the top and middle management teams. The senior managers were socialized to paternalistic sports policies in state socialism and most of them were unable to change their way of thinking in the new political democracy. However we observed the survival of old values, norms, and behaviours not only with senior managers. Shockingly many members of the younger generation expressed such old-fashioned views on the role of the state and civil society, as if they had been socialized in state socialism to believe in the so-called socialist sport model. No doubt, freedom has a contradictory nature in this respect, since the individuals must accept responsibility for their decisions and they cannot shift it onto someone else.The individuals' hesitation between desire for freedom and paternalistic "safety" can be regarded as an ontological feature, as a fundamental characteristic of social existence, and it may lead to escaping from freedom (Fromm 1993).

Paternalism was a guiding principle in state socialism because its adaptation created favourable opportunity for directing and controlling people and for preventing them from thinking and acting on the basis of personal responsibility. However 15 years after the system change the formal political regime cannot be blamed totally for the survival of paternalistic expectations, even if we believe what Dahrendorf predicted, namely:

\section{A Kormányzat civil stratégiája. 2000, Budapest, Miniszterelnöki Hivatal}

"The formal process of constitutional reform takes at least six months; a general sense that things are moving up as a result of economic reform is unlikely to spread before six years have passed; the third condition of the road to freedom is to provide the social foundations which transform the constitution and the economy from fair-weather institutions which can withstand the storms generated from within and without, and sixty years are barely enough to lay these foundations" (Dahrendorf 1990, p. 92-93). 
Paternalistic expectations could survive so extensively because Hungarian sport policy has not been free of paternalism even since the 1989-1990 system change and because it has been related to over-politicization and re-centralization. Patronizing or over-patronizing sports federations, associations, and clubs loyal or committed to political parties and/or politicians has been a factor in political battles, and it justified the endeavours for re-centralization. An open paternalist sport policy could be witnessed at the end of the 1990s and in the early 2000s. Several examples could be given to illustrate that when distributing public funds political fellow feelings hold priority to professional criteria. On other occasions politicians took on outstanding roles in leading sport clubs or national federations, and spent public money on them as if this money had been their own (Bakonyi 2004). Since that time such extreme manifestations of paternalism could not have been noticed. However, paternalism has not disappeared from sport policy. In many cases decisions have been made occasionally, based on separate bargaining, and the ever-changing legal background made it possible. There is a chance paternalism will diminish, but only if some basic conditions are changed, such as (taken from Hédi and Földesi 2004):

- To increase the proportion of state aid to be given to sport from the central state budget (from $0.25 \%$ to at least $1 \%$ );

- To oblige the regional and local municipalities to include sport-related expenditure in their budget (at least $1 \%$ of their budget);

- To rethink the concept of public participation in sport and its partial transfer to the civil sector, albeit with state financial support;

- To reconstruct the original nature of civil and private sectors to the functioning and financing of sport;

- To decrease the disparity of state financing between the individual fields of sport;

- To improve the cooperation between sport and other social sectors such as education, public health;

- To preserve the national traditions but to adapt Hungarian sport to the changing conditions set up by globalization in general and to European integration in particular.

\section{Concluding Thoughts}

Drawing the final conclusion it can be stated that the changes in sport were undergone in a rather contradictory way in the years following the 1989-1990 political system change, and they have been undergone in an even more controversial manner in the post-transformational period. Hungarian sport won a few battles but eventually it lost the war. Organizational restructuring occurred several times but was not accompanied by relevant changes in the approach to sport both on a top and middle managerial level. Neither a modernized sport model nor a national sport strategy, on which a new model should be built, have been founded. There seems to be an aversion and resistance to modernization. A more democratic, a more just, and a truly modern turnaround is still expected. Transformation of Hungarian sport is continuing.

\section{REFERENCES}

Bakonyi, T. (2004). PhD Thesis. Civil Demokrácia és politikus állam. Budapest: Semmelweis University.

Dahrendorf, R. (1990). Reflection on the Revolution in Europe. London: Chatto and Windus. 
Diamond, L. (1994). Rethinking Civil Society. Journal of Democracy. 5:3, pp. 15-17.

Földesi, S. G. (1993). The Transformation of Sport in Eastern Europe: The Hungarian Case. Journal of Comparative Physical Education and Sport. XV:1, pp. 5-21.

Földesiné, Sz. Gy. (1996). A magyar sport átalakulása az 1989-1990-es rendszerváltás után. In Földesiné Sz. Gy. (szerk.): A magyar sport szellemi körképe. Budapest: OTSH-MOB, pp. 13-52.

Frenkl, R., Gallow, R. (2002). Fehér könyv. Helyzetkép a magyar sportról. Kézirat.

Fromm, E. (1993). menekülés a szabadságtól. Budapest: Akadémiai Kiadó.

Heinemann, K. (1990). Two Different Models of Sport for All in a New Germany: Contradictions and Synergy. In XI. USP Congress Perugia, December 6-9.

Hédi, Cs., Földesi Sz. Gy. (2004). Sport Structures in Hungary. In Tokarski, W. et al. (Eds.) Two Players One Goal? Sport in the European Union. Aachen: Meyer und Meyer Verlag, pp. 169-183.

Ibsen, B., Jorgensen (2001). The Cultural and the Voluntary Development of Sport for All in Denmark. In Da Costa, L., Miragaya, A. (Eds.) Worldwide Experiences and Trends in Sport for All. Meyer und Meyer Verlag, Aachen, pp. 293-322.

Krawczyk, Z. (1992). Sport in the Era of Structural Changes: the Example of Eastern Europe. International Review for the Sociology of Sport. 1, pp. 89-97.

Krawczyk, Z., Kosiewicz, J., Pieat, K. (1997). (Eds.) Sport w procesie integracji europejskiej. Warszawa: AWF.

Laskai, Z. (2003). Állam és civil társadalom viszonya. Politikatudományi füzetek. 12, pp. 3-35.

Riordan, J. (1989). Szabadidősport és rekreáció a Szovjetunióban a glasznoszty idején. Testnevelés és Sporttudomány. 4, pp. 287-301.

Riordan, J. (1990). Playing the New Rules: Soviet Sport and Perestroika. 42, p. 133.

Takács, F. (1996). Testkultúránk aktuális problémái a rendszerváltás után. In Földesi, S. G. (szerk.) A magyar sport szellemi körképe. Budapest: OTSH-MOB. 